Review

\title{
Global Burden of Human Papillomavirus and Related Diseases
}

\author{
David Forman $^{\mathrm{a}, *}$, Catherine de Martel $^{\mathrm{b}}$, Charles J. Lacey ${ }^{\mathrm{c}}$, Isabelle Soerjomataram ${ }^{\mathrm{a}}$, \\ Joannie Lortet-Tieulent ${ }^{\mathrm{a}}$, Laia Bruni ${ }^{\mathrm{d}}$, Jerome Vignat ${ }^{\mathrm{b}}$, Jacques Ferlay ${ }^{\mathrm{a}}$, Freddie Bray ${ }^{\mathrm{a}}$, \\ Martyn Plummer ${ }^{\mathrm{b}}$, Silvia Franceschi ${ }^{\mathrm{b}}$ \\ a Section of Cancer Information, International Agency for Research on Cancer, Lyon, France \\ ${ }^{\mathrm{b}}$ Infection and Cancer Epidemiology Group, International Agency for Research on Cancer, Lyon, France \\ c Centre for Immunology E Infection, Hull York Medical School, University of York, York, UK \\ d Unit of Infections and Cancer (UNIC), Cancer Epidemiology Research Program (CERP), Institut Català d'Oncologia - Catalan Institute of Oncology (ICO), \\ L'Hospitalet de Llobregat (Barcelona), Spain
}

\section{A R T I C L E I N F O}

\section{Article history:}

Received 14 June 2012

Received in revised form 9 July 2012

Accepted 17 July 2012

\section{Keywords:}

HPV

Epidemiology

Global cancer burden

Time trends

Population attributable fraction

Cervical cancer

Oropharyngeal cancer

Anal cancer

Penile cancer

Vaginal cancer

Vulvar cancer

Genital warts

\begin{abstract}
A B S T R A C T
The worldwide prevalence of infection with human papillomavirus (HPV) in women without cervical abnormalities is $11-12 \%$ with higher rates in sub-Saharan Africa (24\%), Eastern Europe (21\%) and Latin America (16\%). The two most prevalent types are HPV16 (3.2\%) and HPV18 (1.4\%). Prevalence increases in women with cervical pathology in proportion to the severity of the lesion reaching around $90 \%$ in women with grade 3 cervical intraepithelial neoplasia and invasive cancer. HPV infection has been identified as a definite human carcinogen for six types of cancer: cervix, penis, vulva, vagina, anus and oropharynx (including the base of the tongue and tonsils). Estimates of the incidence of these cancers for 2008 due to HPV infection have been calculated globally. Of the estimated 12.7 million cancers occurring in 2008 , 610,000 (Population Attributable Fraction $[\mathrm{PAF}]=4.8 \%$ ) could be attributed to HPV infection. The PAF varies substantially by geographic region and level of development, increasing to $6.9 \%$ in less developed regions of the world, $14.2 \%$ in sub-Saharan Africa and 15.5\% in India, compared with $2.1 \%$ in more developed regions, $1.6 \%$ in Northern America and $1.2 \%$ in Australia/New Zealand. Cervical cancer, for which the PAF is estimated to be $100 \%$, accounted for 530,000 (86.9\%) of the HPV attributable cases with the other five cancer types accounting for the residual 80,000 cancers. Cervical cancer is the third most common female malignancy and shows a strong association with level of development, rates being at least four-fold higher in countries defined within the low ranking of the Human Development Index (HDI) compared with those in the very high category. Similar disparities are evident for 5-year survival-less than $20 \%$ in low HDI countries and more than $65 \%$ in very high countries. There are five-fold or greater differences in incidence between world regions. In those countries for which reliable temporal data are available, incidence rates appear to be consistently declining by approximately $2 \%$ per annum. There is, however, a lack of information from low HDI countries where screening is less likely to have been successfully implemented. Estimates of the projected incidence of cervical cancer in 2030, based solely on demographic factors, indicate a $2 \%$ increase in the global burden of cervical cancer, i.e., in balance with the current rate of decline. Due to the relative small numbers involved, it is difficult to discern temporal trends for the other cancers associated with HPV infection. Genital warts represent a sexually transmitted benign condition caused by HPV infection, especially HPV6 and HPV11. Reliable surveillance figures are difficult to obtain but data from developed countries indicate an annual incidence of 0.1 to $0.2 \%$ with a peak occurring at teenage and young adult ages.
\end{abstract}

This article forms part of a special supplement entitled "Comprehensive Control of HPV Infections and Related Diseases” Vaccine Volume 30, Supplement 5, 2012.

(c) 2012 Elsevier Ltd. All rights reserved.

\section{Introduction}

This paper provides an overview of the worldwide prevalence of human papillomavirus (HPV) infection and the associated

\footnotetext{
* Corresponding author. Tel.: +33 4727380 56; fax: +33 472738696 .

E-mail address: formand@iarc.fr (D. Forman).
}

burden of cancer. It provides a brief review of the distribution of HPV infection by geographical region and in relation to body sites for which cancer can be an outcome of such infection (cervix, penis, vagina, vulva, anus and oropharynx). For these body sites, information has been extracted from the GLOBOCAN 2008 database on the total number of cancers diagnosed annually worldwide and this has been used to produce estimates of the proportion of these cancers that are associated with HPV. The overall burden of HPV-associated 
cancer has then been stratified by world region and by level of socioeconomic development. Cervical cancer is the most important type of cancer associated with HPV and the chapter provides a review of the current global descriptive epidemiology of this disease, especially in relation to level of development and, where data allows, an analysis of temporal trends. Similar trends are presented for the five other types of cancer associated with HPV infection. Consideration is also given to the epidemiology of genital warts, the major benign condition associated with HPV infection.

\section{HPV prevalence}

The overall global burden of HPV infection is optimally assessed by the pooling of results from studies in which reliable, qualitycontrolled methods have been used to detect HPV in women with normal cervical cytology. The most comprehensive such metaanalysis, with data extracted from 194 studies and based on testing over one million women using polymerase chain reaction (PCR) or Hybrid Capture ${ }^{\circledR} 2$ (Qiagen Gaithersburg, Inc., MD, USA [formerly known as Digene Corp.]) for HPV detection, indicates that the global prevalence of HPV infection is around 11-12\% (Fig. 1). [1] There is considerable regional variation in this figure with prevalence highest in sub-Saharan Africa (24\%), Eastern Europe (21\%) and Latin America (16\%). Particularly high prevalence is seen in Eastern Africa and the Caribbean, where rates exceed 30\%. In general, there is a division between less and more developed world regions with higher rates observed in the former, although the Eastern European situation represents one exception to this pattern, while rates in Northern Africa (9\%) and Western Asia (2\%) represent another. There is a relationship between HPV prevalence and age seen globally, which shows maximum rates in younger women (less than 25 years) with a monotonic decline at older ages (Fig. 2). In Europe and Northern America, HPV prevalence rates are very high below age 25 years but tend to become much lower in women over the age of 45 years. No such clear decline with age is found in Asian and African populations, although in some Latin America/Caribbean populations, rates decline and then increase again in middle-aged women [2]. Data from a subset of the studies in the meta-analysis, in which type-specific HPV information could be assessed, showed
AdjustedaHPV prevalence (\%)

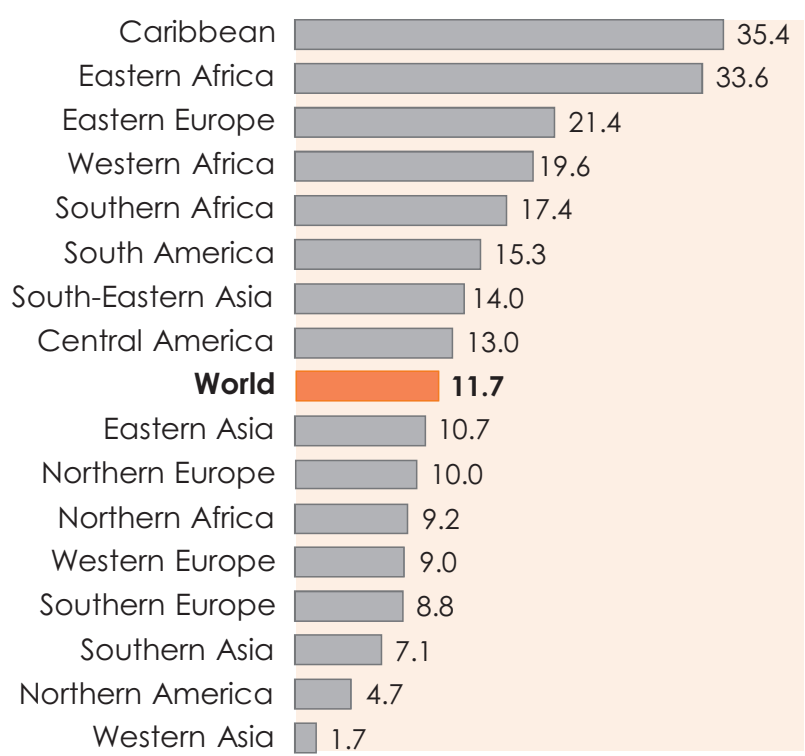

Figure 1. HPV prevalence among women with normal cytology: meta-analysis

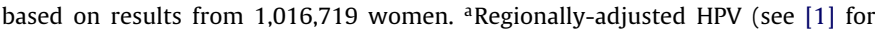
adjustment methodology). Redrawn from Bruni L et al. [1].

that the five most prevalent types worldwide were HPV16 (3.2\%), HPV18 (1.4\%), HPV52 (0.9\%), HPV31 (0.8\%) and HPV58 (0.7\%) [1]. All other HPV types had a prevalence of $0.6 \%$ or less, including HPV45 (0.5\%-along with HPV16 and HPV18-common in invasive cancer), as well as HPV6 (0.5\%) and HPV11 (0.2\%) (the two most prevalent types found in association with genital warts). All of the above estimates represent point prevalence at the time of sampling and will, therefore, be underestimates of the cumulative exposure to infection.

Another recent meta-analysis included results obtained from 423 studies that evaluated testing with broad spectrum consensus PCR assays and which compared over 260,000 women with normal cytology and 103,000 women with cervical abnormalities
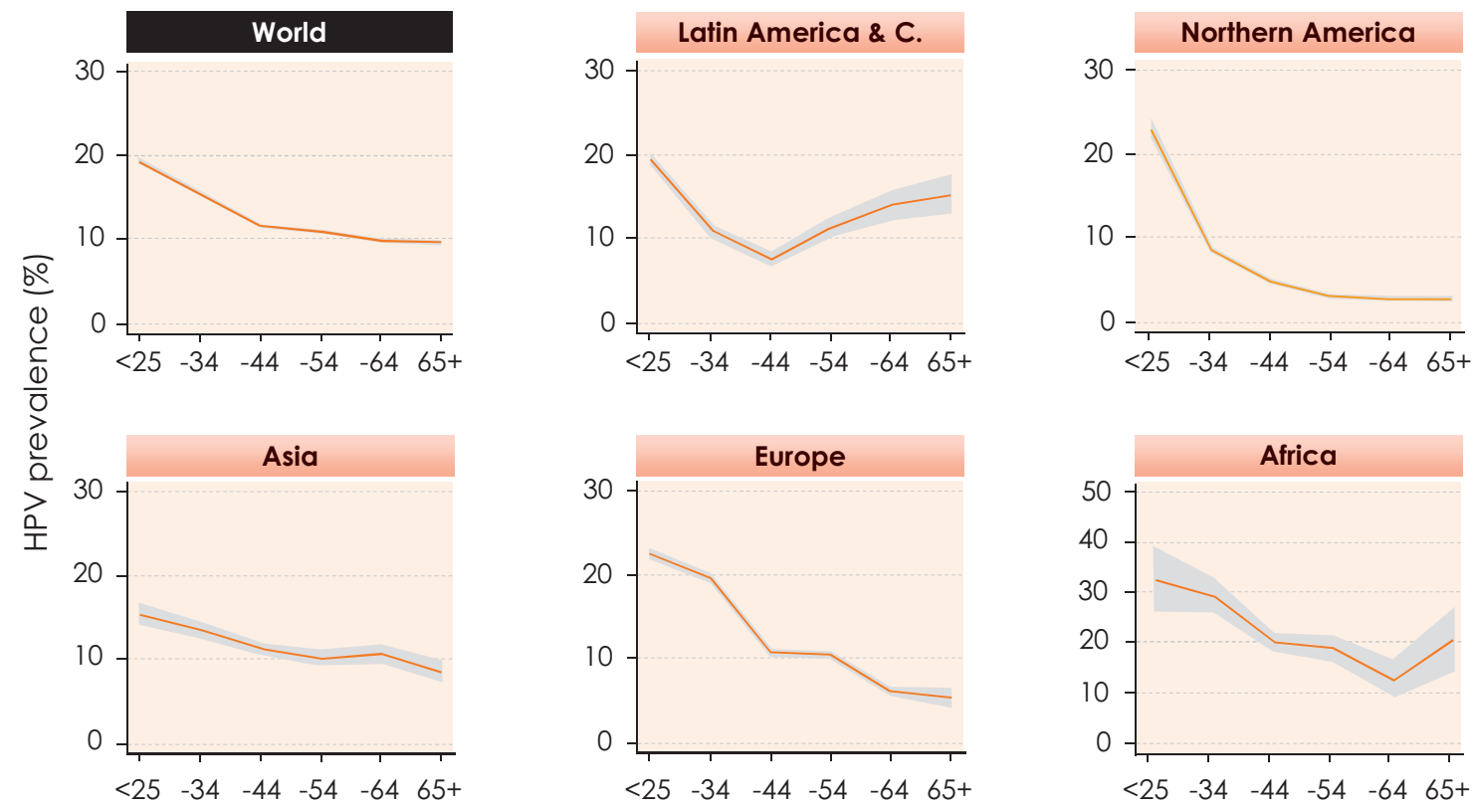

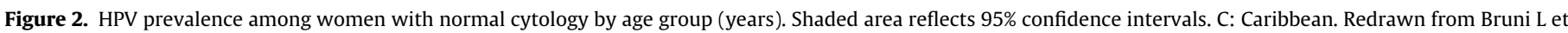
al. [1]. 
Table 1

Results from meta-analysis showing number of women tested for HPV and HPV16, number and percent positive by cervical disease grade.

\begin{tabular}{|c|c|c|c|c|}
\hline Grade of cervical disease & Number of women tested & Number of women HPV-positive & Percentage HPV-positive & Percentage HPV16-positive ${ }^{a}$ \\
\hline Normal cytology & 266611 & 33154 & 12 & 20 \\
\hline ASCUS & 12983 & 6810 & 52 & 23 \\
\hline LSIL & 17805 & 13480 & 76 & 25 \\
\hline HSIL & 7743 & 6616 & 85 & 48 \\
\hline CIN1 & 11043 & 8108 & 73 & 28 \\
\hline CIN2 & 4754 & 4068 & 86 & 40 \\
\hline CIN3 & 11618 & 10753 & 93 & 58 \\
\hline ICC & 40679 & 36374 & 89 & 63 \\
\hline
\end{tabular}

a Among HPV-positives.

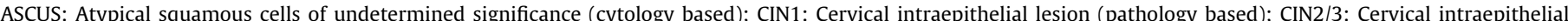

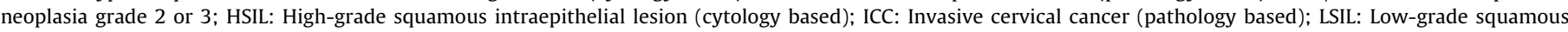
intraepithelial lesion (cytology based).

Based on Guan P et al. [3].

(including 36,000 with invasive cancer). In keeping with the former meta-analysis, this study reported an overall HPV positivity rate of $12 \%$ in women with no abnormalities [3]. The study also showed increases in prevalence in women with cytological abnormalities with the rates increasing in direct proportion to the severity of the lesion reaching around $90 \%$ in women with grade 3 cervical intraepithelial neoplasia (CIN3) and invasive cervical cancer (Table 1). Notably, the proportion of detection of HPV16 among HPV-positive women greatly increases with the increase of severity of cytological and histological findings. The study also reviewed the prevalence of specific high-risk HPV types in women with normal and abnormal cytology. The three most commonly found HPV types in women with invasive cancer-HPV16, 18 and 45-were found, as a proportion of all HPV positive samples, in $20 \%, 8 \%$ and $5 \%$, respectively, of women with normal cytology (and 63\%, 16\% and 5\%, respectively, of women with cancer). Other high risk HPV types were found to each represent between $3 \%$ and $8 \%$ of HPV positive samples from women with normal cytology. The most common high-risk HPV type, HPV16, represented between 13\% (in Africa) and 30\% (in West and Central Asia) of all HPV types in women with normal cytology.

In contrast with the substantial data available regarding global HPV prevalence in cervico-vaginal specimens, less information is available from other body sites, where HPV infection represents a risk factor for cancer. The detection of genital HPV infection in men is influenced by cell sampling techniques [4]. HPV is most commonly detected in the shaft, glans, and scrotum and, much less so, in the urethra. Male genital HPV prevalence, however, is generally well correlated with the prevalence of genital HPV infection in women in the same population [5]. HPV positivity in men, however, tended to vary much less by age group than in women [4]. HPV infection is relatively frequently detected also in the peri-anal region and anal canal in both sexes. By far the highest anal HPV prevalence is found in human immunodeficiency virus (HIV)-positive individuals and men having sex with men (MSM). High-risk HPV types can be detected in the majority of HIV-positive MSM (73.5\%; 95\% confidence interval [CI]: 63.7-83.0\%) [6]. Notably, incidence rates of anal cancer among HIV-positive MSM in the United States of America (USA) are similar to those of cervical cancer in women in sub-Saharan Africa [7].

The detection of oral HPV infection also varies substantially by study, partly depending on sample technique and publication bias [8]. Pooled prevalence of oral HPV infection was 4.5\% (95\% CI: $3.9-5.1 \%$ ) in a meta-analyses of 4581 cancer-free individuals from 18 studies. The largest population-based survey of oral HPV infection was carried out in the USA in 5501 individuals aged 14-69 years [9]. HPV prevalence was 6.9\% (95\% CI: 5.7-8.3\%) and was three-fold higher in men than women and in smokers than never smokers. Data on HPV prevalence in the oropharynx and tonsil are very limited due to the difficulty of cell collections from these sites in healthy populations.

HPV prevalence in the anogenital tract and in the oral cavity is positively associated with different indicators of sexual activity. Anal intercourse is especially associated with HPV detection in the anal canal [6], whereas oral HPV prevalence is associated with orogenital intercourse [9].

\section{Cancers attributable to HPV infection - global and regional burden and population attributable fraction estimates for 2008}

Infection with high-risk HPV is recognized as one of the major causes of infection-related cancer worldwide (along with Helicobacter pylori and hepatitis viruses B and C) [10]. In this section, we consider those cancer sites for which IARC Monograph 100B $[11,12]$ stated that there was strong evidence for a causal etiology with HPV and for which HPV could be considered a group 1 (definite human) carcinogen. For each of these sites of cancer, the population attributable fraction (PAF) has been calculated globally and within 12 major countries/world regions, using statistics on estimated cancer incidence for the year 2008 obtained from GLOBOCAN $2008[13,14]$. Estimates for less and more developed regions were also calculated. The PAF is defined as the proportion of new cancer cases in a population that would have been prevented following a hypothetical intervention that would completely prevent HPV exposure.

\subsection{Cancer sites}

The following cancer sites were considered in IARC Monograph $100 \mathrm{~B}$ as having strong evidence for a causal relationship with HPV: cervix uteri (ICD10 - C53), penis (C60), vulva (C51), vagina (C52), anus (C21) and oropharynx, including base of the tongue and tonsils (C01, C09, C10). Other oral cavity cancers were not included in this list as the epidemiological evidence summarized in the IARC Monograph was not assessed as "strong" [12]. Our approach in selecting HPV-associated cancers was deliberately conservative in order to avoid potentially misleading, inflated estimates of the PAF based on less clear evidence.

\subsection{Cancer incidence data}

Estimates of the number of new cancer cases in 2008 were directly available from GLOBOCAN 2008 for the cancers of the cervix uteri. Some specific cancer sub-sites were not readily available in GLOBOCAN 2008, because they were registered within a broader category. Anal cancer (C21) was included in the broader 
Table 2

Methods for the calculation of the Population Attributable Fraction associated with HPV by cancer site.

\begin{tabular}{|c|c|c|c|c|}
\hline \multirow[b]{2}{*}{ Cancer site or subsite (ICD-10 code) } & \multicolumn{4}{|c|}{ Prevalence of human papillomaviruses (high-risk types) in cancer cases } \\
\hline & $\begin{array}{l}\text { Laboratory method used } \\
\text { for measurement of } \\
\text { exposure }\end{array}$ & $\begin{array}{l}\text { Geographical } \\
\text { area }\end{array}$ & $\begin{array}{l}\text { Prevalence in cases as an } \\
\text { approximation of PAF (\%) }\end{array}$ & Comments and Strength of the data used \\
\hline Cervix uteri carcinoma (C53) & PCR in tumor tissue/cells & World & 100 & $\begin{array}{l}\text { High-risk HPV types are considered a necessary } \\
\text { cause for cervical cancer. This is supported by an } \\
\text { abundant literature. } \\
\text { Strong data }\end{array}$ \\
\hline Penile carcinoma ${ }^{\mathrm{a}}(\mathrm{C} 60)$ & PCR in tumor tissue & World & 50 & $\begin{array}{l}\text { Assumption that the detection of high-risk HPV } \\
\text { DNA in tumor tissue signifies that the cancer is } \\
\text { attributable to HPV. Data based on a recent } \\
\text { meta-analysis [49]. } \\
\text { Limited data }\end{array}$ \\
\hline Anal carcinoma ${ }^{a}(\mathrm{C} 21)$ & PCR in tumor tissue & World & 88 & $\begin{array}{l}\text { Same assumption as for penile cancer. Data } \\
\text { based on a recent meta-analysis [50]. } \\
\text { Strong data }\end{array}$ \\
\hline Vulvar carcinoma ${ }^{\mathrm{a}}$ (C51) & PCR in tumor tissue & World & 43 & $\begin{array}{l}\text { Same assumption as for penile cancer. Data } \\
\text { based on a recent meta-analysis [ } 50] \text {. } \\
\text { Limited data }\end{array}$ \\
\hline Vaginal carcinoma $^{\mathrm{a}}$ (C52) & PCR in tumor tissue & World & 70 & $\begin{array}{l}\text { Same assumption as for penile cancer. Data } \\
\text { based on a recent meta-analysis [50]. } \\
\text { Limited data }\end{array}$ \\
\hline $\begin{array}{l}\text { Oropharyn } x^{\mathrm{a}} \text { including tonsils and } \\
\text { base of tongue (C01, C09-C10) }\end{array}$ & $\begin{array}{l}\text { PCR in tumor tissue with } \\
\text { E6, E7 expression }\end{array}$ & $\begin{array}{l}\text { North America } \\
\text { Northern and } \\
\text { Western Europe } \\
\text { Eastern Europe } \\
\text { Southern Europe } \\
\text { Australia } \\
\text { Japan } \\
\text { Rest of world }\end{array}$ & $\begin{array}{l}56 \\
39 \\
\\
38 \\
17 \\
45 \\
52 \\
13\end{array}$ & $\begin{array}{l}\text { Few prevalence studies available outside the } \\
\text { more developed regions. Same assumption as for } \\
\text { penile cancer except for the difficulty to tease } \\
\text { out the strong effect of tobacco and alcohol. } \\
\text { Limited data }\end{array}$ \\
\hline
\end{tabular}

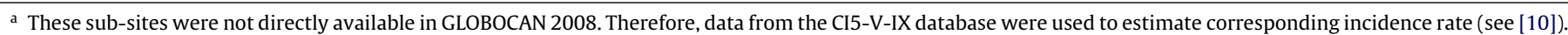
PAF: Population Attributable Fraction; PCR: Polymerase chain reaction.

colorectal cancer category (C18-C21). Oropharyngeal sites, including tonsils and base of tongue (ICD code C01, C09, and C10), were included as part of "Lip, oral cavity" (C00-08) and "other pharynx" (C09-10, C12-14) categories. Vulva, vagina and penile carcinoma were within the broader "other and unspecified" category. For these cancers, the number of cases was imputed by multiplying the estimated number of cases in the broader GLOBOCAN 2008 category by the proportion of cancer sub-sites or sub-types from cancer registry data. These proportions were stratified by eight global regions, age and sex. In general, they were derived from the same registry data used to produce the GLOBOCAN 2008 estimates.

The global regions considered (see details and map in [10]) are based on United Nationals (UN) geographical regions and correspond to those used in GLOBOCAN 2008. Additional estimates were computed specifically for China, India, Japan, and Australia/New Zealand because of the size of their populations within their respective regions. Countries were classified by development status using the UN definition [15]. The "more developed" category comprised all countries within Europe and Northern America, as well as Australia, New Zealand and Japan; "less developed" comprised the remainder.

\subsection{Sources of prevalence and PAF estimation}

Sources of data used for the PAF estimations are summarized in Table 2. For all HPV-related cancers, we considered that the detection by PCR of high-risk HPV DNA in tumor tissue signifies that the cancer is attributable to HPV. Hence, the regular formulas for attributable risk calculation using a measure of the prevalence in the population and an estimate of the relative risk [16] were not used to compute PAF in HPV-related sites. Instead, the prevalence of high-risk HPVs in cancer cases was considered a good approximation to the PAF (Table 2).

\subsection{Estimated HPV-associated burden of cancer}

Table 3 shows the estimated number of cancers attributed to HPV, classified by geographic region, and cancer site. Of the 12.7 million new cancers occurring in 2008 worldwide, 700,000 occurred at an HPV-associated cancer site (cervix uteri, anus, penis, vulva, vagina, and oropharynx) and an estimated 610,000 of these were attributable to HPV. This represents $4.8 \%$ of the total burden of cancer worldwide, slightly lower than a previous estimate of $5.2 \%$, from 2002 data [17], although the estimated absolute number of cases increased from 561,000 in the earlier analysis to the current figure of 610,000 .

This PAF varies widely by geographic region, from $1.2 \%$ in Australia and New Zealand to $14.2 \%$ in Sub-Saharan Africa and $15.5 \%$ in India. Of note, 490,000 cases attributable to HPV (80.6\% of the total) occurred in less developed regions. This is equivalent to $6.9 \%$ of the total cancer burden in such regions compared with $2.1 \%$ in more developed regions.

Table 4 shows a more detailed breakdown of attributable cases by cancer site, cross-tabulated by sex, age group and development status. Cervical cancer accounted for most of the attributable cases (86.9\%) with the other five cancer types accounting for the residual 80,000 cancers. Younger women showed a high burden of HPVrelated cancer, with almost half the cases occurring before the age of 50 years.

Overall, an estimated $610,000(4.8 \%)$ of the 12.7 million new cancer cases occurring in 2008 could be attributable to HPV worldwide.

\section{Cancers attributable to HPV infection - global and regional burden of cervical cancer in 2008}

Of the 610,000 cancers attributable to HPV infection worldwide, the vast majority $(530,000,86.9 \%)$ are cancers of the cervix uteri. 
Table 3

Estimated number of new cancer cases occurring in 2008 attributable to HPV infection by geographic region.

\begin{tabular}{|c|c|c|c|c|c|c|c|c|c|}
\hline REGION & $\begin{array}{l}\text { Total All } \\
\text { cancer sites }\end{array}$ & $\begin{array}{l}\text { Total HPV-related } \\
\text { cancer sites }^{\mathrm{a}}\end{array}$ & $\begin{array}{l}\text { Total attributable } \\
\text { to HPV }\end{array}$ & $\operatorname{PAF}(\%)$ & $\begin{array}{l}\text { Cervix } \\
\text { uteri }\end{array}$ & Anus & Penis & $\begin{array}{l}\text { Vulva/ } \\
\text { Vagina }\end{array}$ & Oro-pharynx \\
\hline \multicolumn{10}{|l|}{ AFRICA } \\
\hline Sub-Saharan Africa & 550,000 & 82,000 & 78,000 & 14.2 & 75,000 & 1,500 & 330 & 940 & 390 \\
\hline Northern Africa and Western Asia & 390,000 & 12,000 & 11,000 & 2.8 & 9,200 & 900 & $<100$ & 620 & 110 \\
\hline \multicolumn{10}{|l|}{ ASIA } \\
\hline India & 950,000 & 170,000 & 150,000 & 15.5 & 130,000 & 2,800 & 3,500 & 3,400 & 3,200 \\
\hline Other Central Asia & 470,000 & 48,000 & 43,000 & 9.0 & 39,000 & 1,800 & $<100$ & 500 & 780 \\
\hline China & $2,800,000$ & 85,000 & 80,000 & 2.8 & 75,000 & 1,500 & 1,200 & 1,100 & 440 \\
\hline Japan & 620,000 & 12,000 & 11,000 & 1.8 & 8,900 & 630 & 120 & 360 & 950 \\
\hline Other Eastern Asia & $1,000,000$ & 62,000 & 55,000 & 5.4 & 51,000 & 1,500 & 1,000 & 1,200 & 710 \\
\hline \multicolumn{10}{|l|}{ AMERICA } \\
\hline Central and Southern America & 910,000 & 84,000 & 75,000 & 8.3 & 68,000 & 2,300 & 1,400 & 2,000 & 780 \\
\hline Northern America & $1,600,000$ & 35,000 & 26,000 & 1.6 & 12,000 & 3,900 & 670 & 2,900 & 6,200 \\
\hline \multicolumn{10}{|l|}{ EUROPE } \\
\hline Europe & $3,200,000$ & 110,000 & 80,000 & 2.5 & 55,000 & 6,800 & 2,400 & 7,400 & 8,100 \\
\hline \multicolumn{10}{|l|}{ OCEANIA } \\
\hline Australia/New Zealand & 130,000 & 2,100 & 1,600 & 1.2 & 800 & 280 & $<100$ & 190 & 230 \\
\hline Other Oceania & 8,800 & 920 & 840 & 9.4 & 800 & $<100$ & $<100$ & $<100$ & $<100$ \\
\hline Less developed regions & $7,100,000$ & 550,000 & 490,000 & 6.9 & 450,000 & 12,000 & 7,600 & 9,800 & 6,400 \\
\hline More developed regions & $5,600,000$ & 150,000 & 120,000 & 2.1 & 77,000 & 12,000 & 3,200 & 11,000 & 15,000 \\
\hline WORLD & $12,700,000$ & 700,000 & 610,000 & 4.8 & 530,000 & 24,000 & 11,000 & 21,000 & 22,000 \\
\hline
\end{tabular}

a HPV-associated cancer sites are: cervix uteri, vulva, vagina, anus, penis and oropharynx including base of tongue and tonsils.

PAF: Population Attributable Fraction.

Based on de Martel et al. [10].

The descriptive epidemiology of this disease provides, therefore, a characterization of the majority of HPV-associated cancer. As infection with high-risk HPV is now viewed as a necessary precondition for the development of all cervical cancer; the disease description does not require stratification into HPV-associated and non-associated sub-types.

Cervical cancer was estimated to be the third most common female malignancy worldwide in 2008 (530,000 new cases), after breast and large bowel cancers, and the fourth most common cause of female death from cancer (275,000 deaths), after breast, lung and large bowel cancers (Table 5). In terms of prevalence, there were an estimated 1.6 million women, aged over 15 years, alive with a diagnosis of cervical cancer made in the previous 5 years, second only to breast cancer [18]. Finally, in terms of global indicators, cervical cancer was the cause of an estimated 7.8 million years of life lost (YLL) in women, third after breast and lung cancers.

There is a well characterised and strong association between cervical cancer incidence and level of development, and approximately $86 \%$ of the incident cases and $88 \%$ of the deaths are estimated to occur in less developed regions of the world [19]. More detailed analyses, by levels of the human development index (HDI - a country specific, composite index based on life expectancy, literacy, access to education and per capita gross domestic product) [20] shows a clear relationship with cervical cancer incidence, mortality and other indicators (Table 5 and Fig. 3). Incidence and mortality rates tend to be at least four-fold higher in low HDI countries (predominantly in sub-Saharan Africa) compared with very high HDI countries with intermediate levels seen in medium and high HDI countries. Using data from EUROCARE [21] and SURVCAN [22] reveals a similar pattern for 5-year relative survival (Fig. 4): less than $20 \%$ in low HDI countries and more than $65 \%$ in very high HDI countries. Prognosis of cervical cancer depends largely on the stage at diagnosis and availability and accessibility of adequate diagnostic and treatment facilities; therefore, there are major differences between countries with and without screening programs.

Global maps (Fig. 5) and comparative regional rates for cervical cancer (Fig. 6) show patterns of variation largely consistent with the association with level of HDI. As seen in Fig. 6, there is a five- to sixfold variation between highest (sub-Saharan Africa, Southern Asia and South America) and lowest (Northern America, Australia/New Zealand and Western Europe) risk regions. While this heterogeneity is essentially associated with developmental level, the low risk

Table 4

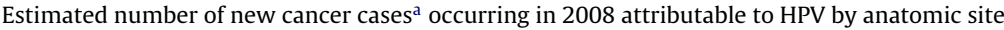

\begin{tabular}{|c|c|c|c|c|c|c|c|c|c|c|}
\hline \multirow[t]{2}{*}{$\begin{array}{l}\text { HPV-RELATED } \\
\text { CANCER SITE }\end{array}$} & \multirow[t]{2}{*}{$\begin{array}{l}\text { Number of new } \\
\text { cases in } 2008\end{array}$} & \multirow[t]{2}{*}{$\begin{array}{l}\text { Number } \\
\text { attributable } \\
\text { to HPV }\end{array}$} & \multirow[t]{2}{*}{$\operatorname{PAF}(\%)$} & \multicolumn{2}{|c|}{$\begin{array}{l}\text { Number attributable } \\
\text { to infection by gender }\end{array}$} & \multicolumn{3}{|c|}{$\begin{array}{l}\text { Number attributable to infection } \\
\text { by age group }\end{array}$} & \multicolumn{2}{|c|}{$\begin{array}{l}\text { Number attributable to } \\
\text { infection by development } \\
\text { status }\end{array}$} \\
\hline & & & & Males & Females & $<50$ years & 50 to 69 years & $70+$ years & $\begin{array}{l}\text { Less } \\
\text { developed } \\
\text { regions }\end{array}$ & $\begin{array}{l}\text { More } \\
\text { developed } \\
\text { regions }\end{array}$ \\
\hline Cervix uteri & 530,000 & 530,000 & 100.0 & 0 & 530,000 & 250,000 & 220,000 & 59,000 & 450,000 & 77,000 \\
\hline Vulva & 27,000 & 12,000 & 43.0 & 0 & 12,000 & 1,700 & 3,900 & 6,000 & 4,100 & 7,500 \\
\hline Anus & 27,000 & 24,000 & 88.0 & 11,000 & 13,000 & 5,100 & 10,000 & 8,300 & 12,000 & 12,000 \\
\hline Penis & 22,000 & 11,000 & 50.0 & 11,000 & 0 & 2,500 & 4,800 & 3,500 & 7,600 & 3,200 \\
\hline Vagina & 13,000 & 9,000 & 70.0 & 0 & 9,000 & 2,000 & 4,000 & 3,100 & 5,700 & 3,400 \\
\hline Oropharynx ${ }^{\mathrm{b}}$ & 85,000 & 22,000 & 25.6 & 17,000 & 4,400 & 4,300 & 13,000 & 4,600 & 6,400 & 15,000 \\
\hline $\begin{array}{l}\text { TOTAL HPV } \\
\text { RELATED SITES }\end{array}$ & 700,000 & 610,000 & 86.3 & 39,000 & 570,000 & 270,000 & 260,000 & 85,000 & 490,000 & 120,000 \\
\hline
\end{tabular}

\footnotetext{
a Numbers rounded to two significant digits.

b Includes tonsils and base of tongue.

PAF: Population Attributable Fraction.

Based on de Martel et al. [10].
} 
Table 5

Worldwide burden of cervical cancer, GLOBOCAN 2008 estimates $^{\mathrm{a}}$ by level of Human Development Index (HDI) ${ }^{\mathrm{b}}$.

\begin{tabular}{|c|c|c|c|c|c|}
\hline \multirow[t]{2}{*}{ Indicator } & \multirow[t]{2}{*}{2008 estimate } & \multicolumn{4}{|c|}{ Proportion (\%) of burden by level of Human Development Index ${ }^{c}$} \\
\hline & & Low & Medium & High & Very high \\
\hline Number of new cases & 530,000 & 6 & 67 & 17 & 9 \\
\hline Number of deaths & 275,000 & 8 & 69 & 16 & 7 \\
\hline Five-year prevalence ${ }^{\mathrm{d}}$ & $1,555,000$ & 5 & 64 & 19 & 11 \\
\hline Years of life lost & $7,800,000$ & 9 & 71 & 15 & 5 \\
\hline
\end{tabular}

a Ferlay J et al. [13].

b United Nations Development Program [20].

c Human Development Index (HDI) categories: low = HDI <0.5; medium = HDI 0.5-0.7; high = HDI 0.7-0.9; very high = HDI >0.9.

d Above age 15 years.

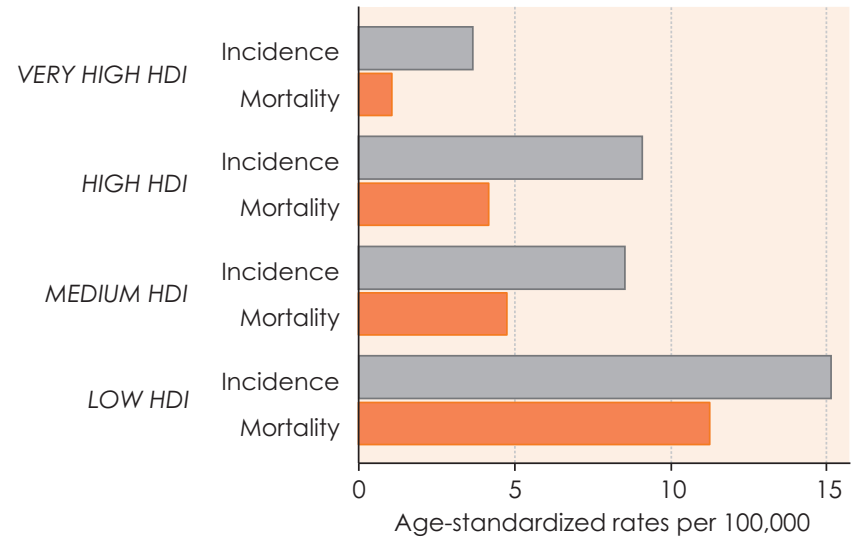

Figure 3. Cervical cancer, age-standardized (world standard) incidence (in grey) and mortality (in orange) rates (all ages) per 100,000 in 2008 by level of Human Development Index (HDI). Based on GLOBOCAN 2008 [13].

of cervical cancer in the predominantly Muslim regions of North Africa and Western Asia, in keeping with the low prevalence of HPV infection as observed above, is indicative of the importance of cultural environment and related behavioural patterns. It should be emphasised that large heterogeneity in cervical cancer incidence and mortality is also invariably observed within, as well as between, regions. This is well documented in the paper by Arbyn $\mathrm{M}$ et al. [19], showing usually 10 -fold or greater variation in rates between countries within regions. Even within a relatively affluent area such as Northern Europe, with uniformly high standards of cancer registration, there is a five-fold variation in incidence between the high rates of Lithuania and the low rates of Finland

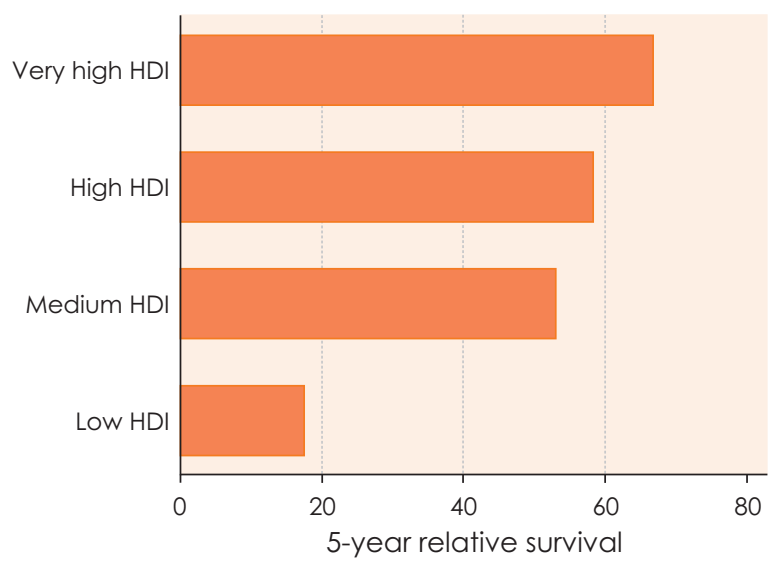

Figure 4. Cervical cancer, age-standardized (world standard) 5-year relative survival (all ages) according to level of Human Development Index (HDI) in patients diagnosed with cancer around 1990-2001. Based on Eurocare-4 [21] (for European populations) and Sankaranrayanan $\mathrm{R}$ et al. [22] (for non-European populations). Survival by HDI was calculated as countries (non-weighted) average.
(Fig. 7). Such differences are due predominantly to the combination of HPV prevalence per se and the presence (and effectiveness) of population-based screening programs (for example highly effective in Finland and lacking population coverage in Lithuania) [23].

\section{Cancers attributable to HPV infection - temporal trends in cervical cancer}

In order to examine trends over time, use has been made of sequential datasets submitted by cancer registries and published in Cancer Incidence in Five Continents (CI5C) [24]. Such data, for a selected sample of registries that have provided results for five 5year time periods and extended in the case of the USA-Surveillance Epidemiology and End Results (SEER) populations [25], are shown in Fig. 8. The registries included represent medium (India-Mumbai, Philippines-Manila), high (Colombia-Cali) and very high (Denmark, Japan-Miyagi, USA-SEER white and black) HDI countries. Although there is substantial variation in terms of the age standardized incidence rates observed (e.g., in 1983-87, over 35 per 100,000 in Cali to less than 10 per 100,000 in the SEER White and Miyagi populations), the incidence is declining at a broadly similar rate in all populations and, with the exception of Miyagi, especially in the more recent time period. While the absolute incidence rates will, to a certain extent [26], reflect the prevalence of high-risk HPV infection in the respective populations (or at least the prevalence in an earlier time period), the decline is predominantly a result of the introduction of effective population-based screening procedures combined with a range of sociocultural factors, including access to health care, changes in age at marriage and family planning behaviour, and improvements in education. Such changes appear to have commenced later in Mumbai (decline starting in 1988-92) than elsewhere [27].

A more general overview of global time trends is presented in Fig. 9 (taken from [28]). This provides a summary of the estimated annual percentage change (EAPC), together with associated $95 \% \mathrm{CIs}$, by cancer registry population for all the registries providing data to CI5C over the 1988-2002 time period (101 populations in total), stratified by HDI level. Most populations have EAPC rates that are significantly lower than zero, i.e., indicative of a statistically significant decline during the time period. Unfortunately, most of the available datasets are from very high HDI populations with only a small number from middle HDI populations and none at all from low HDI populations. The mean EAPC across all of the very high HDI populations is $-2.6 \%$ while in the high and medium HDI populations it is $-1.2 \%$ and $-1.8 \%$, respectively. While this is suggestive of an overall worldwide decline in incidence, this is not universally the case. Thus, there are a small number of populations represented in Fig. 9 in which the EAPC is either not decreasing or is even increasing. These populations are mainly from parts of East and South East Asia (Thailand Chang-Mai) and Eastern Europe (Lithuania, Latvia, Estonia) where, in the absence of effective screening, 


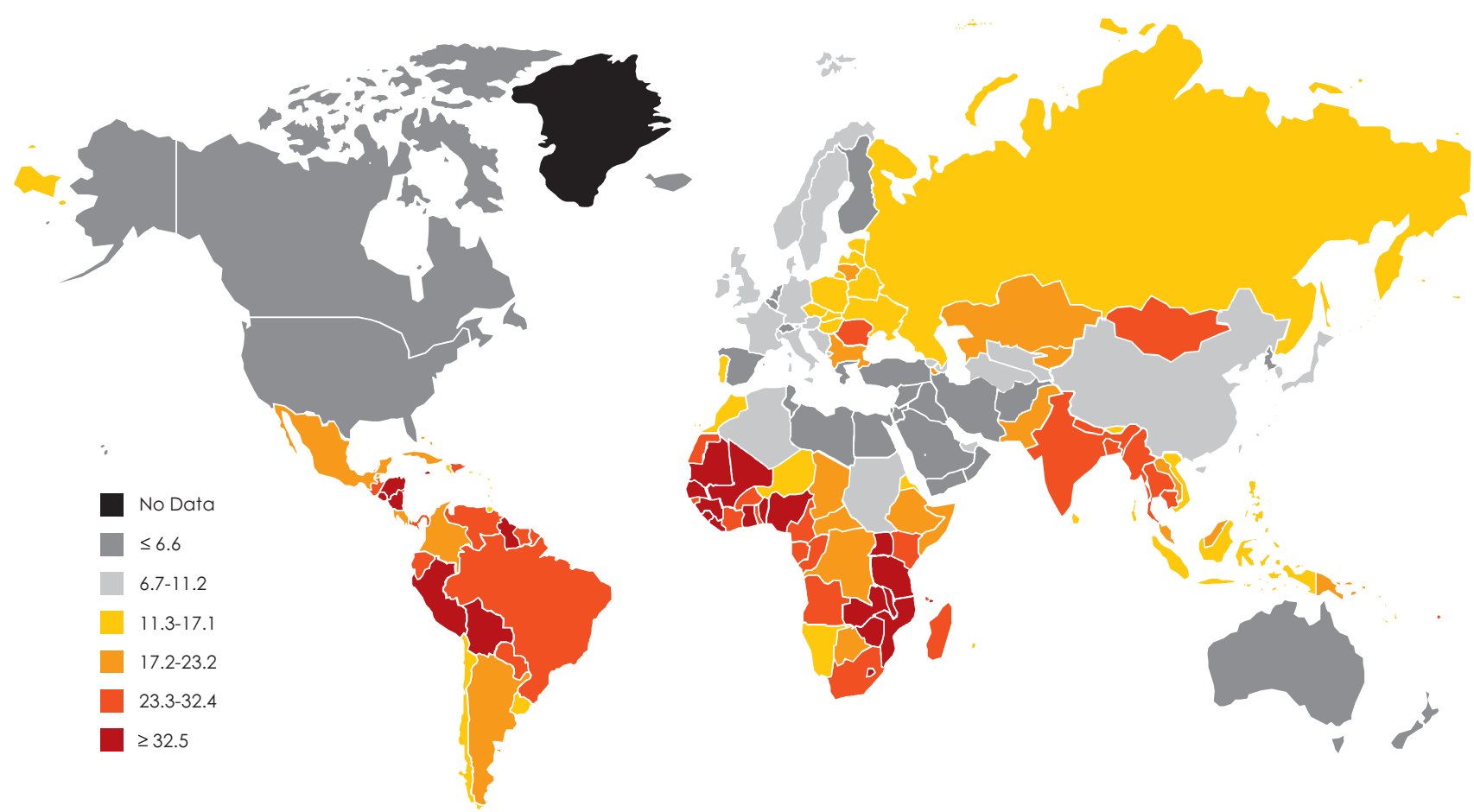

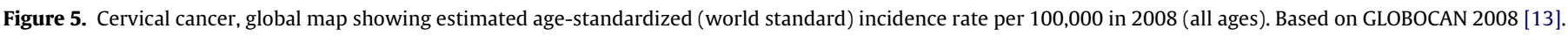

incidence has increased in successive generations of women as a result of changing sexual behaviour and increasing risk of persistent HPV infection. There is also significant uncertainty about the situation in low HDI countries, not included in Fig. 9, often with populations in which rates are particularly high and cervical cancer represents the most frequently diagnosed cancer type. These will also invariably be countries less likely to have implemented population-based screening. There is at least one specific report, from Uganda, of incidence increasing in such a population [29] and the lack of adequate information from low HDI countries is a major deficiency in understanding changes in the global burden.

GLOBOCAN makes available a facility for projection of the likely burden of cancer up until 2030 based entirely on estimated changes in population demographics, i.e., the growth in the population and the changes in its age structure. On this basis, the current global annual burden of cervical cancer, 530,000 new cases in 2008, is estimated to increase by approximately $2 \%$ per annum to 770,000 new cases by 2030 , with the vast majority of cases diagnosed in less developed regions of the world (Fig. 10). The $2 \%$ annual increase due to demographics very crudely "balances" the mean decrease observed in EAPC $(-1.2 \%$ to $-2.6 \%)$ in the analysis of registry data from 1988-2002 in more developed countries. In other words, if the current decline in global age-standardized rates continues at around $2 \%$ per annum and is observed uniformly in different regions of the world, the absolute burden of disease will remain approximately constant. Thus, in order to reduce the absolute burden, it will be necessary to improve on the $2 \%$ annual reduction in age-standardized incidence rate. Clearly, improved screening technologies and HPV vaccination offer this perspective. However, the uncertainties regarding trends in some areas of the world,

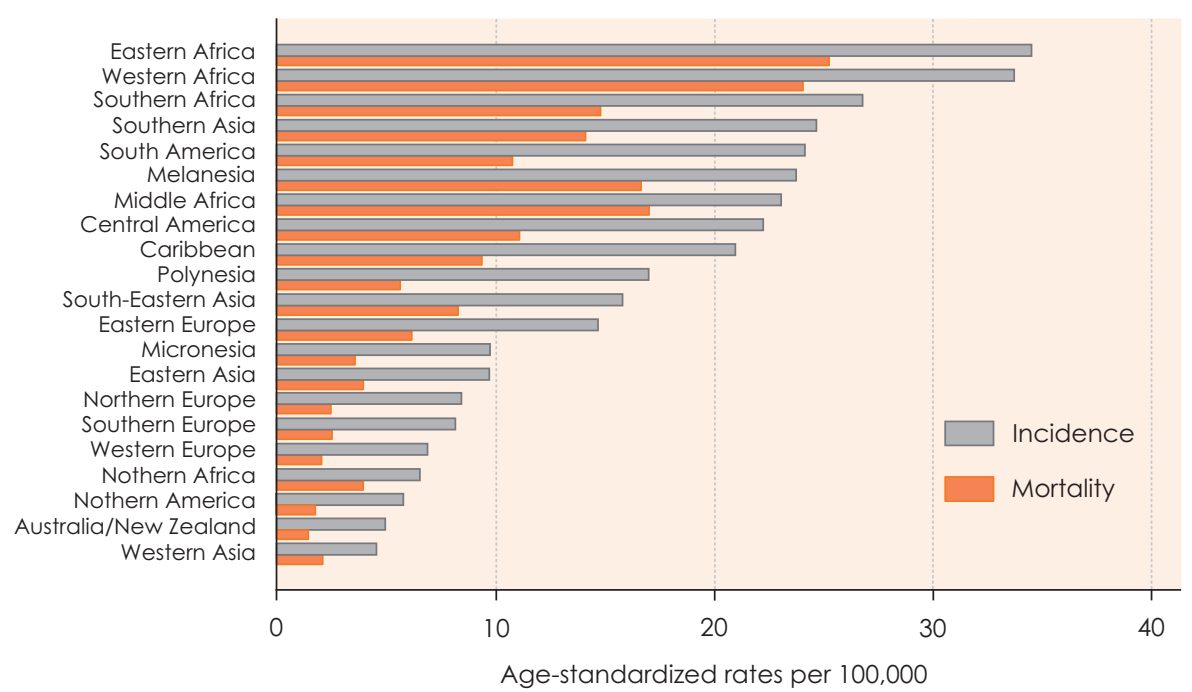

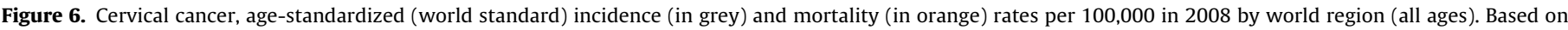
GLOBOCAN 2008 [13]. 


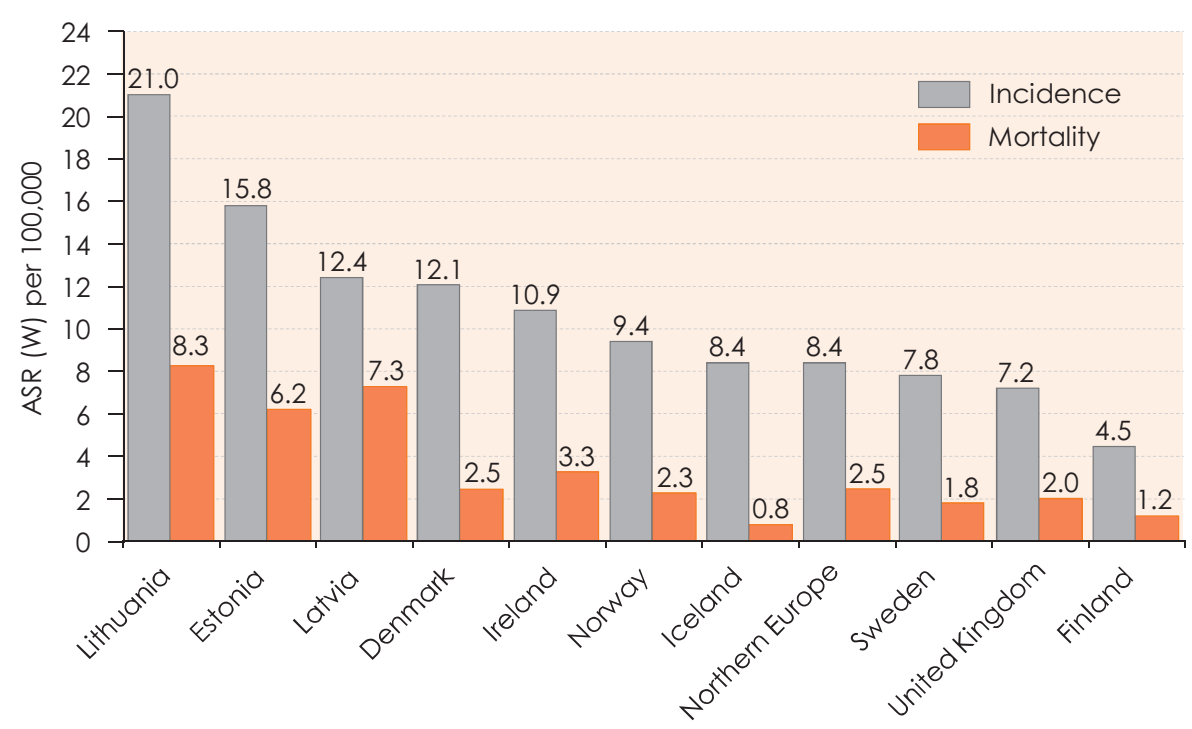

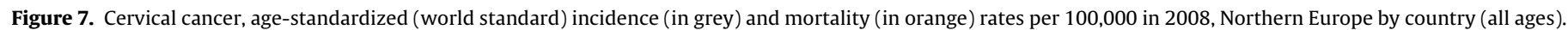
Based on GLOBOCAN 2008 [13]. ASR (W): Age-standardized (world standard) rate.

especially low HDI countries, have the potential to distort this crude analysis, especially if such regions are showing underlying increases in HPV prevalence.

\section{Cancers attributable to HPV infection - temporal trends in cancers other than the cervix}

Fig. 11 shows time trends for the other HPV-associated cancer sites (oropharynx, anus, penis, vagina and vulva) and for the same registry populations and time periods as presented in Fig. 8 for cervical cancer. As can be readily observed, the age-standardized rates for these cancers were of a different magnitude than those for cervical cancer. Whereas rates for the latter varied, depending on population and time period, from 5 to 40 per 100,000, for none of the five sites considered in Fig. 11 did the rates ever exceed 2 per 100,000 . Partly because of the likely random fluctuations inherent to the small numbers involved and possible underreporting of anogenital cancer in less developed countries, it is also very difficult to discern trends within these cancers. It is, however, notable that the population from Japan-Miyagi consistently has the lowest rates for all sites, except oropharyngeal cancer, for which incidence appears to have increased over the time period considered. The Japanese population also had the lowest rates for cervical cancer. With the exception of data from India-Mumbai and PhilippinesManila, all other populations showed evidence of recent increases in anal cancer, the only one of the sites considered for which there is an indication of a temporal trend. More detailed review of the international time trends for oropharyngeal cancer is presented in the chapter by Gillison ML et al., Vaccine, this issue [30]. As seen in Table 2, unlike cervical cancer, this group of cancers is not entirely attributable to HPV infection and thus other risk factors may influence the descriptive epidemiology. Thus, for example, tobacco use

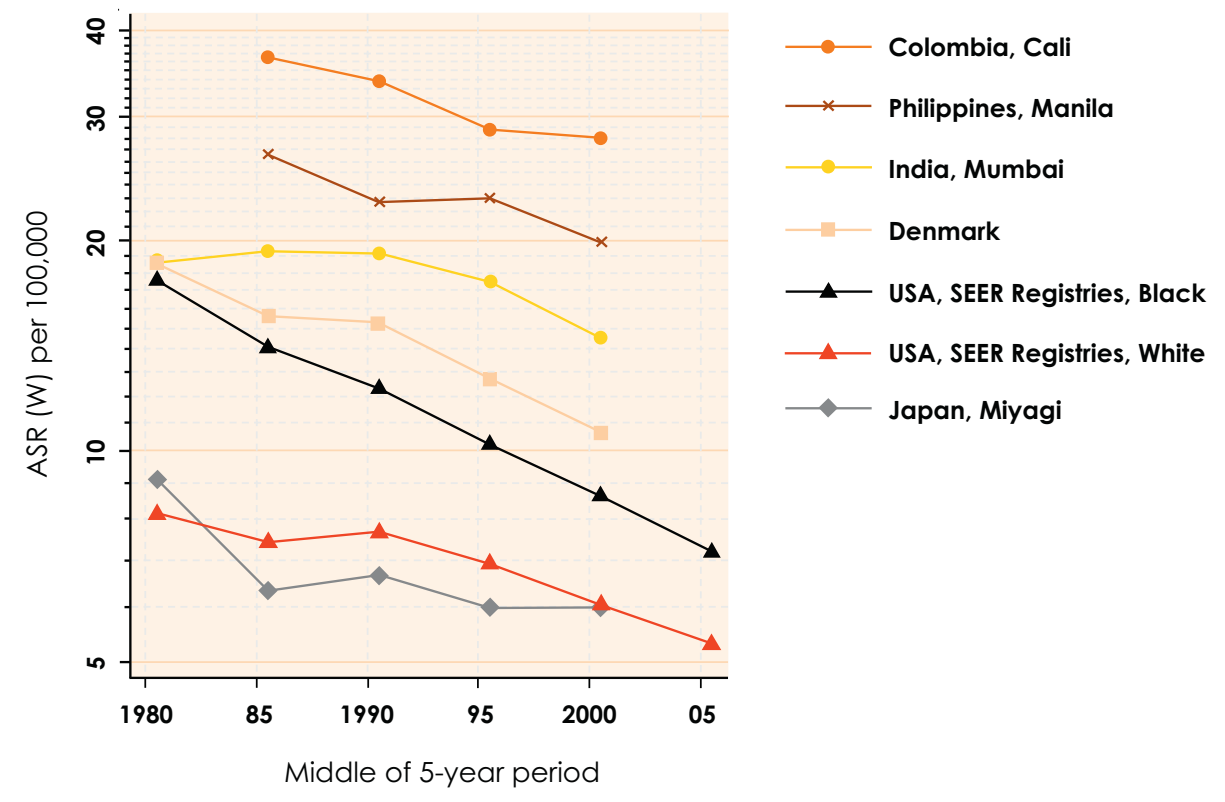

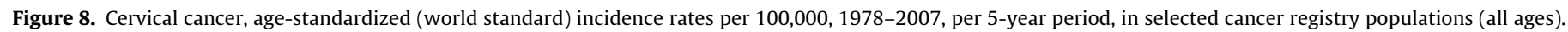

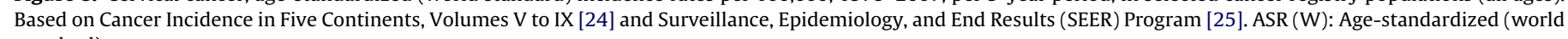
standard) rate. 


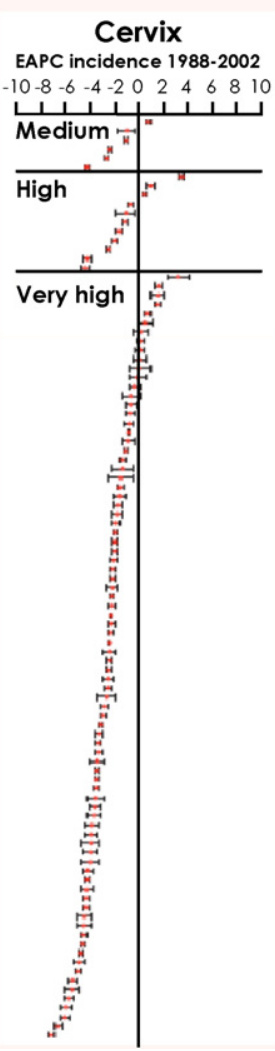

Figure 9. Cervical cancer, estimated annual percentage change (EAPC) in agestandardized (world standard) incidence, 1988-2002, all ages, 101 cancer registry populations, by categories of Human Development Index. Redrawn from Bray F et al. [28].

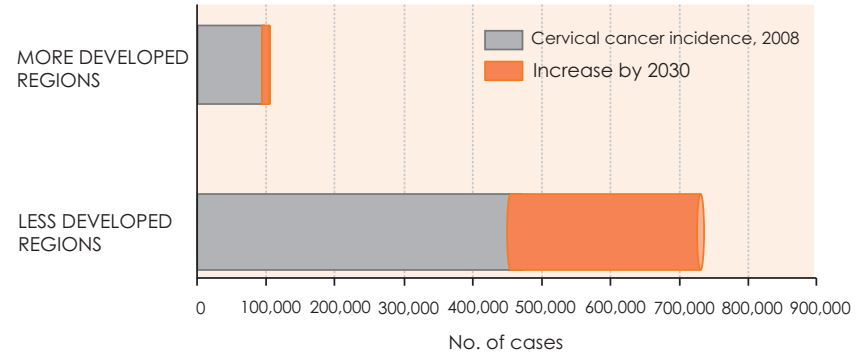

Figure 10. Estimated global burden of cervical cancer incidence, 2008 (grey) and increase by 2030 (orange) by more and less developed regions of the world. Based on GLOBOCAN 2008 [13].

has a strong association with head and neck cancers, including oropharyngeal cancers, and incidence trends will be reflective of both this and high risk HPV exposure.

\section{Genital warts}

Genital warts (GW) are a sexually transmitted infection (STI) usually caused by HPV6 or HPV11. Different series have recorded differences in the distribution of HPV genotypes in GW lesions, but some of the most methodologically rigorous studies have found HPV6/11 in 96-100\% of all GW lesions [31-33]. In the developed world, genital warts show similar epidemiological features to other common STIs with a peak incidence in young people aged 15-24 years [34]. Not all subjects will present to healthcare facilities for evaluation. There are a variety of treatments for GW but recurrence is seen with all treatments [35]. Therefore, new presentations of subjects with genital warts can either represent first-attack episodes or recurrent episodes, and these episodes may be prolonged, which adds complexity to the interpretation of surveillance data. The United Kingdom (UK) has the longest established national reporting system for genital warts, dating from 1971. This showed
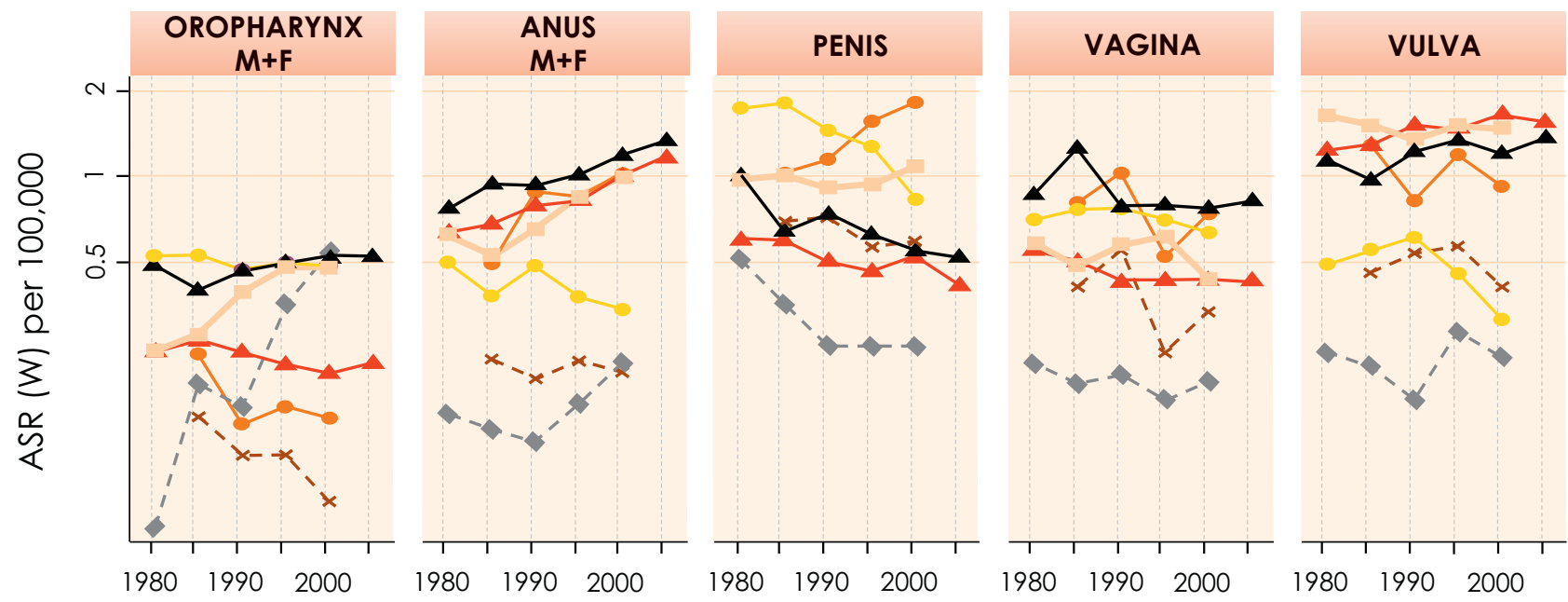

Period
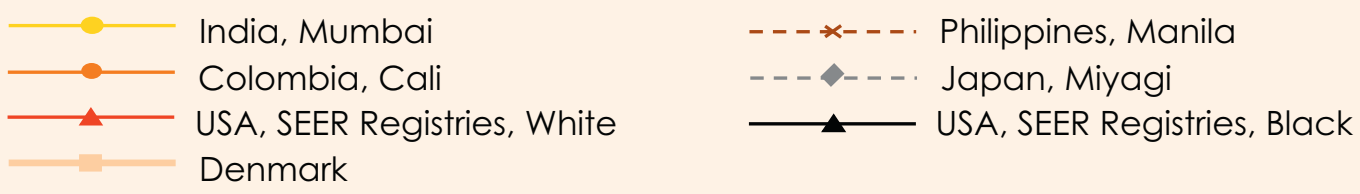

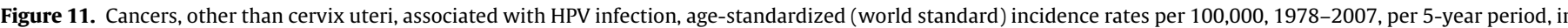

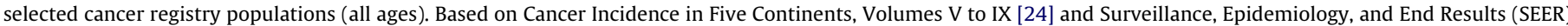

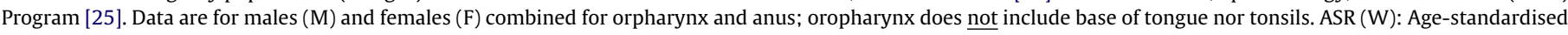
(world standard) rate. 
Table 6

Worldwide incidence and prevalence of genital warts.

\begin{tabular}{|c|c|c|c|c|}
\hline Country/Region/Ref & Time period & Population/Data & $\begin{array}{l}\text { Incidence/new cases per } \\
\text { annuma }^{\mathrm{a}}\end{array}$ & $\begin{array}{l}\text { Prevalence/recurrent cases } \\
\text { per annuma }\end{array}$ \\
\hline UK - England [51] & 2008 & Combined STI clinic \& GP data & $0.16 \%$ & $0.13 \%$ \\
\hline Canada - Manitoba [41] & 1985-2004 & Combined STI clinic, GP \& hospital data & $0.16 \%(1992)$ & $0.15 \%(2004)$ \\
\hline Canada - British Columbia [52] & $1998-2006$ & Combined STI clinic, GP \& hospital data & $\begin{array}{l}0.11 \%(1999) \text { to } 0.13 \% \\
(2006)\end{array}$ & $\begin{array}{l}0.11 \%(1998) \text { to } 0.15 \% \\
(2006)\end{array}$ \\
\hline USA [53] & 2000 & $\begin{array}{l}\text { Commercial healthcare plan } \\
\text { population }\end{array}$ & $\begin{array}{l}0.17 \% \text { (per privately } \\
\text { insured population) }\end{array}$ & - \\
\hline USA [54] & $1998-2001$ & $\begin{array}{l}\text { Commercial healthcare plan } \\
\text { population }\end{array}$ & $\begin{array}{l}0.20 \% \text { ( } 2001 \text {, per privately } \\
\text { insured population) }\end{array}$ & - \\
\hline USA [55] & 2004 & $\begin{array}{l}\text { Commercial healthcare maintenance } \\
\text { organization }\end{array}$ & $0.12 \%$ & - \\
\hline Australia[56] & 2000-2006 & $\begin{array}{l}\text { General practitioner data; also quotes } \\
\text { an 'STI clinic adjustment factor' }\end{array}$ & $\begin{array}{l}0.17 \% \text { (unadjusted) } 0.22 \% \\
\text { (adjusted) }\end{array}$ & - \\
\hline France [57] & 2005 & Women consulting gynaecologists & $\begin{array}{l}0.23 \% \text { (per females aged } \\
16-65 y r s)\end{array}$ & - \\
\hline Netherlands [58] & $2006 \& 2007$ & Combined STI clinic \& GP data & $0.13 \%$ & - \\
\hline
\end{tabular}

a Rates are population based, male and female combined, all ages, unless stated otherwise.

GP: General practitioner; STI: Sexually-transmitted infection.

an approximate eight-fold increase in the total numbers of diagnoses of GW in England over the period 1971-2001 [36]. Data from the Nordic countries based on self reports, and data from the USA based on physician office visits, also show significant increases in GW prevalence over similar time periods $[37,38]$. These increases are presumed to have been due to changes in sexual behaviour, including the lowering of age at sexual debut that has been seen in many developed countries [39]. Incident cases of GW in England rose by 15\% from 2001-2007, but rates appear to have stabilised in the last 5 years [40]. Data from Manitoba, Canada, over the period 1985-2004, showed incidence rates peaking in 1992 [41].

The development of the quadrivalent HPV (qHPV) vaccine has stimulated renewed interest in the population burden and healthcare costs associated with GW. Thus in recent years, data have been published on the incidence and prevalence of GW from a number of countries, including the UK, the USA, Canada, Australia, France, and the Netherlands. Although the sources and methodology differ somewhat, these data are summarised in Table 6 and appear remarkably consistent across the selected developed world countries. These surveillance figures indicate an annual incidence of $0.1-0.2 \%$ with a peak occurring in teenagers and at young adult ages. There remains a dearth of knowledge regarding GW burden in the rest of world, although some data are available for sub-Saharan Africa (see De Vuyst H et al. Vaccine, this issue [42]). In a randomised controlled trial of a vaginal microbicide gel in 9,385 HIV-negative women in four sub-Saharan African countries, an incidence of GW of 0.4 per 100 women years was recorded (McCormack S, personal communication). In a cohort of high risk women attending an HIV/STI clinic in Burkina Faso, incidences of GW per 100 women-years of $1.1 \%$ in HIV-negative and $7.4 \%$ in HIV-positive women were recorded [43].

GW represent a 'short incubation period HPV disease'. Therefore if the efficacy of the qHPV vaccine against HPV6/11 disease that was reported in the pivotal randomised, controlled trials is translated into population-based effectiveness, we may quickly see reductions in, or even potentially elimination, of genital warts [44-48].

In conclusion, GW represent a significant HPV disease burden worldwide, resulting in substantial healthcare costs and loss of quality of life. There is now accumulating evidence that populationbased qHPV vaccination can result in dramatic declines in GW incidence and reduction in HPV6/11 burden.

\section{Conclusions}

HPV infection is the most common STI worldwide and, in many world regions, the majority of sexually active individuals of both sexes will probably acquire it at some time during their lifetime. Variations in genital HPV prevalence by age differ substantially by population. The peak in HPV prevalence among young women should not, therefore, be viewed as the natural history of the infection but, at least in part, as a "westernization" effect (i.e., tendency to have multiple sexual partners at young age) that is not shared by more conservative societies. The 12 most common HPV types in cervical cancer worldwide are, in decreasing order, HPV16 (57\%), 18 (16\%), 58, 33, 45, 31, 52, and 35, with small variations by region [3]. HPV16 is by far the likeliest to persist and cause CIN3 and cervical cancer [12].

HPV infection accounts for approximately $2 \%$ and $7 \%$ of the total cancer burden in more developed and less developed countries, respectively [10]. Contrary to the other similarly important cancercausing infections (Helicobacter pylori and hepatitis B and C virus), $\mathrm{HPV}$ is nearly exclusively sexually transmitted and it is not strongly affected by general improvements in medical and living standards. Therefore, only vaccination and cervical screening can prevent or counteract HPV epidemics and their cancer sequelae in any population. qHPV vaccination would also reduce the burden of GW, a condition associated with high incidence and related health care costs.

\section{Acknowledgements}

The work was partially supported by public grants from the European Commission (7th Framework Programme grant HEALTHF3-2010-242061, PREHDICT), from the Instituto de Salud Carlos III (Spanish Government) (grants FIS PI10/02995, RCESP C03/09, RTICESP C03/10, RTIC RD06/0020/0095 and CIBERESP) and from the Agència de Gestió d'Ajuts Universitaris i de Recerca - Generalitat de Catalunya (Catalonian Government) (grants AGAUR 2005SGR00695 and AGAUR 2009SGR126), who had no role in data collection, analysis or interpretation of results.

\section{Disclosed potential conflicts of interest}

CJL: Has received support for travel and attending meetings form GSK and SPMSD.

LB: Institutional support: HPV vaccine trials and epidemiological studies sponsored by GlaxoSmithKline, Merck and Sanofi Pasteur MSD. Screening and HPV testing trials partially supported by Qiagen. Personal support: Travel grants to conferences occasionally granted by Sanofi Pasteur MSD.

DF, CdM, IS, JLT, JV, JF, FB, MP, SF: Have disclosed no potential conflicts of interest. 


\section{References}

[1] Bruni L, Diaz M, Castellsagué X, Ferrer E, Bosch FX, de Sanjosé S. Cervical human papillomavirus prevalence in 5 continents: meta-analysis of 1 million women with normal cytological findings. J Infect Dis 2010;202:1789-99.

[2] Franceschi S, Herrero R, Clifford GM, Snijders PJ, Arslan A, Anh PT, et al. Variations in the age-specific curves of human papillomavirus prevalence in women worldwide. Int J Cancer 2006;119(11):2677-84.

[3] Guan P, Howell-Jones R, Li N, Bruni L, de Sanjosé S, Franceschi S, et al. Human papillomavirus types in 115,789 HPV-positive women: A metaanalysis from cervical infection to cancer. Int J Cancer 2012 Feb 9. http://dx.doi.org/10.1002/ijc.27485 [Epub ahead of print].

[4] Anic GM, Giuliano AR. Genital HPV infection and related lesions in men. Prev Med 2011;53(Suppl 1):S36-41.

[5] Franceschi S, Castellsagué X, Dal Maso L, Smith JS, Plummer M, Ngelangel C, et al. Prevalence and determinants of human papillomavirus genital infection in men. Br J Cancer 2002;86(5):705-11.

[6] Machalek DA, Poynten M, Jin F, Fairley CK, Farnsworth A, Garland SM, et al. Anal human papillomavirus infection and associated neoplastic lesions in men who have sex with men: a systematic review and meta-analysis. Lancet Oncol 2012;13(5):487-500. Epub 2012 Mar 23.

[7] Silverberg MJ, Lau B, Justice AC, Engels E, Gill MJ, Goedert JJ, et al. North American AIDS Cohort Collaboration on Research and Design (NA-ACCORD) of IeDEA Risk of anal cancer in HIV-infected and HIV-uninfected individuals in North America. Clin Infect Dis 2012;54(7):1026-34. Epub 2012 Jan 30.

[8] Kreimer AR, Bhatia RK, Messeguer AL. Oral human papillomavirus in healthy individuals: a systematic review of the literature. Sex Transm Dis 2010;37(6):386-91.

[9] Gillison ML, Broutian T, Pickard RK, Tong ZY, Xiao W, Kahle L, et al. Prevalence of oral HPV infection in the United States, 2009-2010. JAMA 2012;307(7):693-703. Epub 2012 Jan 26.

[10] De Martel C, Ferlay J, Franceschi S, Vignat J, Bray F, Forman D, et al. The global burden of cancers attributable to infections in the year 2008: a review and synthetic analysis. Lancet Oncol 2012;13:607-15.

[11] Bouvard V, Baan R, Straif K, Grosse Y, Secretan B, El Ghissassi F, et al. A review of human carcinogens-Part B: biological agents. Lancet Oncol 2009 Apr;10(4):321-2.

[12] Proceedings of the IARC Working Group on the Evaluation of Carcinogenic Risks to Humans. Biological Agents. Lyon, France, 24 February-3 March 2009 IARC Monogr Eval Carcinog Risks Hum Vol 100B 2011. Available at: http://monographs.iarc.fr/ENG/Monographs/vol100B/index.php.(last accessed July 2012).

[13] Ferlay J, Shin HR, Bray F, Forman D, Mathers C, Parkin DM. GLOBOCAN 2008 v1.2, Cancer Incidence and Mortality Worldwide: IARC CancerBase No. 10 [Internet] Lyon, France: International Agency for Research on Cancer; 2010. [Available at: http://globocan.iarc.fr (last accessed April 2012).

[14] Ferlay J, Shin HR, Bray F, Forman D, Mathers C, Parkin DM. Estimates of worldwide burden of cancer in 2008: GLOBOCAN 2008. Int J Cancer 2010;127:2893-917.

[15] World Population Prospects: The 2008 Revision Highlights. New-York; 2009.

[16] Levin ML. The occurrence of lung cancer in man. Acta Unio Int Contra Cancrum 1953;9:531-41.

[17] Parkin DM, Bray F. Chapter 2: The burden of HPV-related cancers. Vaccine 2006;24(Suppl 3):S11-25.

[18] Bray F, Ren J, Masuyer E, Ferlay J. Estimates of global cancer prevalence in 2008 for 27 sites in the adult population. Int J Cancer 2012 Jul 3. http://dx.doi.org/10.1002/ijc.27711. [Epub ahead of print].

[19] Arbyn M, Castellsagué X, de Sanjosé S, Bruni L, Saraiya M, Bray F, et al. Worldwide burden of cervical cancer in 2008. Ann Oncol 2011;22:2675-83.

[20] United Nation Development Programme. Human Development Report 2009: Overcoming barriers: Human mobility and development. New York: United Nation Development Programme, 2009.

[21] EUROCARE: Survival of cancer patients in Europe. Available at http://www.eurocare.it (last accessed April 2012).

[22] Sankaranarayanan R, Swaminathan R, Brenner H, Chen K, Chia KS, Chen JG, et al. Cancer survival in Africa, Asia and Central America: a population-based study. Lancet Oncol 2010;11:165-73.

[23] European Cancer Observatory Cancer Screening cervix uteri. Available at: http://eu-cancer.iarc.fr/cancer-14-display-text-561-565.html,en (last accessed July 2012).

[24] Ferlay J, Parkin DM, Curado MP, et al. Cancer Incidence in Five Continents, Volumes I to IX: IARC CancerBase No. 9 [Internet]. Lyon, France: International Agency for Research on Cancer; 2010. Available at: http://ci5.iarc.fr (last accessed July 2012).

[25] Surveillance, Epidemiology, and End Results (SEER) Program (www.seer.cancer.gov) SEER*Stat Database: Incidence - SEER 9 Regs Research Data, Nov 2010 Sub (1973-2008) <Katrina/Rita Population Adjustment> Linked To County Attributes - Total U.S., 1969-2010 Counties, National Cancer Institute, DCCPS, Surveillance Research Program, Surveillance Systems Branch, released April 2011, based on the November 2010 submission.

[26] Maucourt-Boulch D, Franceschi S, Plummer M, the IARC HPV Prevalence Surveys Study Group. International correlation between Human Papillomavirus prevalence and cervical cancer incidence. Cancer Epidemiol Biomarkers Prev 2008; 17:717-20.
[27] Dhillon PK, Yeole BB, Dikshit R, Kurkure AP, Bray F. Trends in breast, ovarian and cervical cancer incidence in Mumbai, India over a 30-year period, 1976-2005: an age-period-cohort analysis. Br J Cancer 2011;105(5):723-30. http://dx.doi.org/10.1038/bjc.2011.301. Epub 2011 Aug 9.

[28] Bray F, Jemal A, Grey N, Ferlay J, Forman D. Global cancer transitions according to the Human Development Index (2008-2030): a population-based study Lancet Oncol 2012 Aug;13(8):790-801.

[29] Parkin DM, Nambooze S, Wabwire-Mangen F, Wabinga HR. Changing cancer incidence in Kampala, Uganda, 1991-2006. Int J Cancer 2009;126: 1187-95.

[30] Gillison ML, Alemany L, Snijders PJF, Chaturvedi A, Steinberg BM, Schwartz S, et al. Human papillomavirus and disease of the upper airway: head and neck cancer and respiratory papillomatosis. Vaccine 2012;30(S5):F34-54.

[31] Ball SL, Winder DM, Vaughan K, Hanna N, Levy J, Sterling JC, et al. Analysis of human papillomavirus genotypes and viral loads in anogenital warts. J Med Virol 2011;83:1345-50.

[32] Meyer T, Arndt R, Christophers E, Beckmann ER, Schroder S, Gissmann L, et al. Association of rare human papillomavirus types with genital premalignant and malignant lesions. J Infec Dis 1998;178:252-5.

[33] Brown DR, Schroeder JM, Bryan JM, Stoler MH, Fife KH. Detection of multiple human papillomavirus types in condylomata acuminata lesions from otherwise healthy and immunosuppressed patients. J Clin Microbiol 1999;37: 3316-22.

[34] Monteiro EF, Lacey CJN, Merrick D. The interrelationship of demographic and geospatial risk factors between four common sexually transmitted diseases. Sex Transm Infect 2005;81:41-6.

[35] Lacey CJ, Woodhall SC, Wikstrom A, Ross J. 2012 European guideline for management of anogenital warts. JEADV 2012; Mar 12. Doi: 10.1111 (Epub ahead of print).

[36] Lacey CJN, Lowndes CM, Shah KV. Chapter 4: Burden and management of noncancerous HPV-related conditions: HPV-6/11 disease. Vaccine 2006;24(Suppl. 3):S35-41.

[37] Kjaer SK, Tran TN, Sparen P, Tryggvadottir L, Munk C, Dasbach E, et al. The burden of genital warts: a study of nearly 70,000 women from the general female population in the 4 Nordic countries. J Infect Dis 2007;196: 1447-54.

[38] Centers for Disease Control and Prevention. 2010 Sexually Transmitted Diseases Surveillance. Available at: http://www.cdc.gov/std/stats10/figures 50.htm (last accessed June 2012)

[39] Johnson AM, Mercer CH, Erens B, Copas AJ, McManus S, Wellings K, et al. Sexual behaviour in Britain: partnerships, practices, and HIV risk behaviours. Lancet 2001;358:1843-50.

[40] Health Protection Agency UK. Topics: Infectious Diseases HIV and STIs Geographical data. Available at: http://www.hpa.org.uk/webc/HPAwebFile/ HPAweb_C/1215589015024 (last accessed June 2012).

[41] Kliewer EV, Demers AA, Elliott L, Buler JR, Brisson M. Twenty year trends in the incidence and prevalence of diagnosed anogenital warts in Canada. Sex Transm Dis 2009;36:380-6.

[42] De Vuyst H, Alemany L, Lacey C, Chibwesha CJ, Sahasrabuddhe V, Banura C, et al. The burden of human papillomavirus infections and related diseases in sub-Saharan Africa. Vaccine, in press

[43] Low AJ, Clayton T, Konate I, Nagot N, Ouedraogo A, Huet C, et al. Genital warts and infection with human immunodeficiency virus in high-risk women in Burkina Faso: a longitudinal study. BMC Infectious Diseases 2011;11:20.

[44] Lacey CJ, Garnett GP. Promising control of genital warts: but is elimination possible? Lancet Infect Dis 2011;11:4-6.

[45] Donovan B, Franklin N, Guy R, Grulich AE, Regan DG, Ali H, et al. Quadrivalent human papillomavirus vaccination and trends in genital warts in Australia: analysis of national sentinel surveillance data. Lancet Infect Dis 2011;11:39-44.

[46] Read TRH, Hocking JS, Chen MY, Donovan B, Bradshaw CS, Fairley CK. The near disappearance of genital warts in young women 4 years after commencing a national human papillomavirus vaccination programme. Sex Transm In 2011;87:544-7.

[47] Bauer HM, Wright G, Chow J. Evidence of human papillomavirus effectiveness in reducing genital warts: an analysis of California public family planning administrative claims data, 2007-2010. Am J Public Health 2012;102: 833-5.

[48] Flagg EW, Schwartz R, Weinstock H. Prevalence of anaogenital warts among participants in private health plans in the US 2003-2009: potential impact of HPV vaccination. C4.12012 National STD Prevention Conference. Available at: https://cdc.confex.com/cdc/std2012/webprogram/Paper29351.html (last accessed June 2012)

[49] Backes DM, Kurman RJ, Pimenta JM, Smith JS. Systematic review of human papillomavirus prevalence in invasive penile cancer. Cancer Causes Control 2009;20:449-57.

[50] De Vuyst H, Clifford GM, Nascimento MC, Madeleine MM, Franceschi S. Prevalence and type distribution of human papillomavirus in carcinoma and intraepithelial neoplasia of the vulva, vagina and anus: a meta-analysis. Int Cancer 2009;124:1626-36

[51] Desai S, Wetten S, Woodhall SC, Peters L, Hughes G, Soldan K. Genital warts and cost of care in England. Sex Transm Infect 2011:87:464-8.

[52] Marra F, Ogilvie G, Colley L, Kliewer E, Marra CA. Epidemiology and costs associated with genital warts in Canada. Sex Transm Infect 2009;85:111-5.

[53] Insigna RP, Dasbach EJ, Myers ER. The health and economic burden of genital warts in a set of private health plans in the United States. Clin Infect Dis 2003;361:397-403. 
[54] Koshiol JE, Laurent SA, Pimenta JM. Rate and predictors of new genital warts claims and genital warts-related healthcare utilization among privately insured patients in the United States. Sex Transm Dis 2004;31:748-52.

[55] Hoy T, Singhal PK, Willey VJ, Insigna RP. Assessing incidence and economic burden of genital warts with data from a US commercially insured population. Curr Med Res Opin 2009;25:2343-51.

[56] Pirotta M, Stein AN, Conway EL, Harrison C, Britt H, Garland S. Genital warts incidence and healthcare resource utilisation in Australia. Sex Transm Infect 2010;86:181-6.
[57] Monsonego J, Breugelmans JG, Bouee S, Lafuam A, Benard S, Remy V. Anogenital warts incidence, medical management and costs in women consulting gynaecologists in France. Gynecol Obster Fertil 2007;35:107-13.

[58] van den Broek IV, Verheij RA, van Dijk CE, Koedijk FD, van der Sande MA van Bergen JE. Trends in sexually transmitted infections in the Netherlands, combining surveillance data from general practices and sexually transmitted infection centers. BMC Family Practice 2010;11:39. 